Department of Applied Ecology, University of Łódź, Banacha 12/16, 90-237 Łodź, Poland,adwoj@biol.uni.lodz.pl

\title{
THE INFLUENCE OF THE ZEBRA MUSSEL (DREISENA POLYMORHPA) ON MAGNESIUM AND CALCIUM CONCENTRATION IN WATER
}

\begin{abstract}
In this study we examined changes in magnesium and calcium ion concentrations depending on Zebra Mussel biomass, $\mathrm{pH}$ values and temperature. We performed field experiments in years with different weather conditions using twelve 200 litre polycarbonate containers filled with 150 litres of non-filtered water from lowland, eutrophic reservoirs. Three treatments of the experiment were represented by: Phyto control with non-filtered water, Phyto+Dreis A with Zebra Mussel biomass of $500 \mathrm{~g} / \mathrm{m}^{2}$, and Phyto+Dreis B with Zebra Mussel biomass of $1.000 \mathrm{~g} / \mathrm{m}^{2}$. Magnesium and calcium ions concentrations were analyzed on an ion chromatograph (Dionex-1000). Results indicated a significant reduction in magnesium and calcium ion concentrations by Zebra Mussels (independent of mussel biomass), especially in the year with higher and more stable average temperatures. $\mathrm{Mg}$ concentration was significantly negatively correlated with temperature in this year. In both years of study the magnesium and calcium ion concentrations were negatively correlated with $\mathrm{pH}$. Analyses of the Zebra Mussel's impact on magnesium and calcium loss from water, linked with the influence of physical factors (temperature and $\mathrm{pH}$ ), may be valuable for the management of invaded ecosystems.
\end{abstract}

Key words: invasive species, $\mathrm{Mg}, \mathrm{Ca}$, temperature, algal blooms 


\section{INTRODUCTION}

The invasive Zebra Mussel species Dreissena polymorpha Pallas is known as an organism that tolerates a wide range of environmental conditions, which results in its high dispersal capacity (STAŃCZYKOWSKA 1983; O’NEILL 1996; LEWANDOWSKI 2001; CASAGRANDI et al. 2007). It has, in fact, invaded numerous European and North American inland waters (STRAYER 1991), usually causing dramatic changes in the physical and biological structure of the infested ecosystems (MACISAAC 1996; KARATAYEV et al. 2002). However, as the Zebra Mussel originates from the Caspian and Black Seas, colonization of the freshwater environments requires many physiological adaptations. Nevertheless, the water chemistry demands of the Zebra Mussel are extraordinarily complex and not observed in other freshwater bivalves (HoROHOV et al. 1992). Their tolerance to decreased $\mathrm{Na}, \mathrm{Cl}, \mathrm{K}$, and particularly $\mathrm{Mg}$ concentrations in water is very low (DIETZ et al. 1994), and studies show that the Zebra Mussel is absent in Mg-poor lakes (HALLSTAN et al. 2010). RAMCHARAN and co-workers (1992) additionally classified calcium concentration and water $\mathrm{pH}$ as the important factors for the success of Zebra Mussel invasion. Identification of these factors may be crucial for limiting and controlling Zebra Mussel distribution. However, the determination of $D$. polymorpha's influence on the concentration of ions essential for this species' survival may be also valuable for the management of the invaded water bodies. Effective control programs should focus not only on local Zebra Mussel population dynamics but also on the exploration of complex physical, chemical and biological changes impacted by Zebra Mussel activity in monitored ecosystems (O’NEILL 1996; KARATAYEV et al. 2002).

We performed outdoor experiments in years with different weather conditions: in 2007 summer temperature was generally low and fluctuating, but in 2008 summer was warm with relatively stable temperatures. In this study we examined how the presence of the Zebra Mussel contributed to changes in magnesium and calcium ion concentrations in water and whether these changes were correlated with water temperature and $\mathrm{pH}$. Research was conducted into the aspect 
of water quality, because we were interested whether, and to what extent, Zebra Mussels may be $\mathrm{Mg}$-competitors for bloom-forming algae and cyanobacteria.

\section{MATERIALS AND METHODS}

The experiment was conducted from 23 June to 13 September 2007 and 22 June to 18 September 2008 in the Field Station of the University of Łodź located near Sulejów Reservoir. Water and Zebra Mussels used in the experiment were collected from the Sulejów Reservoir $\left(51^{\circ} 22^{\prime}-51^{\circ} 28^{\prime} \mathrm{N}, 19^{\circ} 51^{\prime}-20^{\circ} 01^{\prime} \mathrm{E}\right)$ situated on $138.9 \mathrm{~km}$ of the Pilica River (the Vistula River catchment) in central Poland. The Sulejów Reservoir is a 37-year old, shallow (mean depth is $3.3 \mathrm{~m}$ ) and eutrophic ecosystem, invaded by Zebra Mussel (ABRASZEwSKA 2006). During summer, the cyanobacteria blooms forming mainly by Microcystis aeruginosa (Kutzing) are usually observed (TARCZYŃSKA et al. 2001).

Zebra Mussels were collected in the shallow littoral part of the reservoir. In the laboratory, colonies were cleaned, weighed and placed in aquaria with reservoir water for acclimatization. After $24 \mathrm{~h}$, Zebra Mussels were used in the experiment. Filtering activity of animals was monitored every day. All Zebra Mussels were again weighed and released back to the reservoir after the end of the experiment.

The experiment was conducted under natural light and temperature conditions in twelve 2001 polycarbonate containers $(115 \mathrm{~cm}$ height, $60 \mathrm{~cm}$ diameter) filled with 1501 of non-filtered water from Sulejów Reservoir. There were three treatments prepared of the experiment (in four replicates):

- Phyto (control with non-filtered water from the reservoir);

- Phyto+Dreis A (non-filtered water + $175 \mathrm{~g}$ of Zebra Mussel colonies, which corresponds to a biomass of $500 \mathrm{~g} / \mathrm{m}^{2}$ );

- Phyto+Dreis B (non-filtered water + 350 g of Zebra Mussel colonies, which corresponds to a biomass of $1.000 \mathrm{~g} / \mathrm{m}^{2}$ ).

The containers were put into a concrete ditch filled with water to $2 / 3$ the height of the containers to buffer temperature fluctuations. Before each sampling occasion, water in all containers was mixed. 


\subsection{Physical water analyses}

Water temperature $\left({ }^{\circ} \mathrm{C}\right), \mathrm{pH}$ and total dissolved oxygen - TDO $(\mathrm{mg} / \mathrm{l})$ were measured weekly in each container at 10:00 a.m. using WTW 340i/SET multisensors.

\subsection{Magnesium and calcium ion concentrations}

Magnesium $(\mathrm{Mg})$ and calcium $(\mathrm{Ca})$ ion concentrations were analysed on Dionex-1000, which consists of two ion chromatographies IC, separated for anions and cations. Each IC (Dionex Corporation, ICS-1000) consists of a pump, eluent, guard column (CG18 for cation and AG18 for anions), an analytical column (IonPac CS18 for cation, IonPac AS18 for anions), and an electrolytic suppressor (CSRSULTRA II cation electrolytic suppressor and ASRS - ULTRA II anion electrolytic suppressor) to stabilize the baseline. The analyses were performed by using $16 \mathrm{mM}$ methanesulfonic acid (Fluka) for the cation analysis and a mixture of $4.5 \mathrm{mM}$ sodium carbonate and $1.4 \mathrm{mM}$ sodium bicarbonate for the anion system prepared from the AS22 Eluent Concentrate (produced by Dionex Corporation). Both ICs were operated in isocratic elution in $30{ }^{\circ} \mathrm{C}$ at a flow rate of $1 \mathrm{ml} / \mathrm{min}$. Cation measurements were performed using a $25 \mu \mathrm{l}$ injection loop and anion using a $450 \mu \mathrm{l}$ injection loop. For ion identification, combined standards (Seven Anion Standard II, Dionex Six Cation Standard produced by Dionex Corporation) were used.

\subsection{Concentration of chlorophyll $a$}

For each treatment, the concentration of chlorophyll $a(\mathrm{Chl} a)(\mu \mathrm{g} / \mathrm{l})$ was measured immediately after sampling in a 1-liter water sample using a bbe Algae Online Analyser (AOA, Version 1.5 E1, bbe-Moldaenke company Kiel, Germany). The measurement principle of bbe AOA is based on the determination of the fluorescence spectrum and fluorescence kinetics of the algae (www.bbemoldaenke.de). This online analyser is recognised as reliable for chlorophyll $a$ measurement (CAGNARD et al. 2006) and is a useful tool for monitoring phytoplankton community composition, especially as an early warning system for 
the detection of harmful algal blooms (IZYDORCZYK et al. 2009; RICHARDSON et al. 2010).

\subsection{Statistical methods}

Testing for the treatment effect on the magnesium ion concentration in water, in order to adjust for the effects of both magnesium uptake by algae and $\mathrm{pH}$ variability, we applied an analysis of covariance (ANCOVA) with treatments as categorical factors, magnesium concentrations as the dependent factors, and chlorophyll $a$ concentrations and $\mathrm{pH}$ values as covariate. To test for the treatment effect on both the oxygen and calcium ion concentrations we used an ANOVA with treatments as categorical factors and calcium and oxygen concentrations as dependent factors. Pearson's correlation coefficient was applied for analysing relationships between magnesium and calcium ions concentrations and $\mathrm{pH}$ and temperature.

\section{RESULTS}

\subsection{Zebra Mussel analyses}

We observed permanent filtering activity of Zebra Mussels in all days of the experiment. In both study years, the entire Zebra Mussel weight increased during the experiment (Fig. 1): in 2007 - from 175 to mean $191.21 \mathrm{~g}(\mathrm{SD}=5.48)$ in the Phyto+Dreis A, and from 350 to mean $367.41 \mathrm{~g}(\mathrm{SD}=4.67)$ in the Phyto+Dreis B treatment; in 2008 - from 175 to mean $196.73 \mathrm{~g}(\mathrm{SD}=3.34)$ in the Phyto+Dreis A, and from 350 to mean $381.6 \mathrm{~g}(\mathrm{SD}=5.87)$ in the Phyto+Dreis B treatment.

\subsection{Physical water analyses}

We did not find any significant differences in water temperature and oxygen concentration between the three types of treatments neither in 2007 nor 2008. In 2007 mean temperature was $14.9^{\circ} \mathrm{C}$ (Fig. 2a), ranging from $11.9^{\circ} \mathrm{C}$ to $19.7^{\circ} \mathrm{C}$. Thus, despite the buffering role of water in the concrete ditch, temperature fluctuations were high. These fluctuations were due to variable weather conditions. In 2008, mean temperature was much higher at $18.3^{\circ} \mathrm{C}$ and fluctuated from $17.5^{\circ} \mathrm{C}$ 
to $22.9^{\circ} \mathrm{C}$ between 22 June and 4 September before decreasing to $9.5^{\circ} \mathrm{C}$ in all treatments during the last two weeks of the experiment (Fig. 2b).

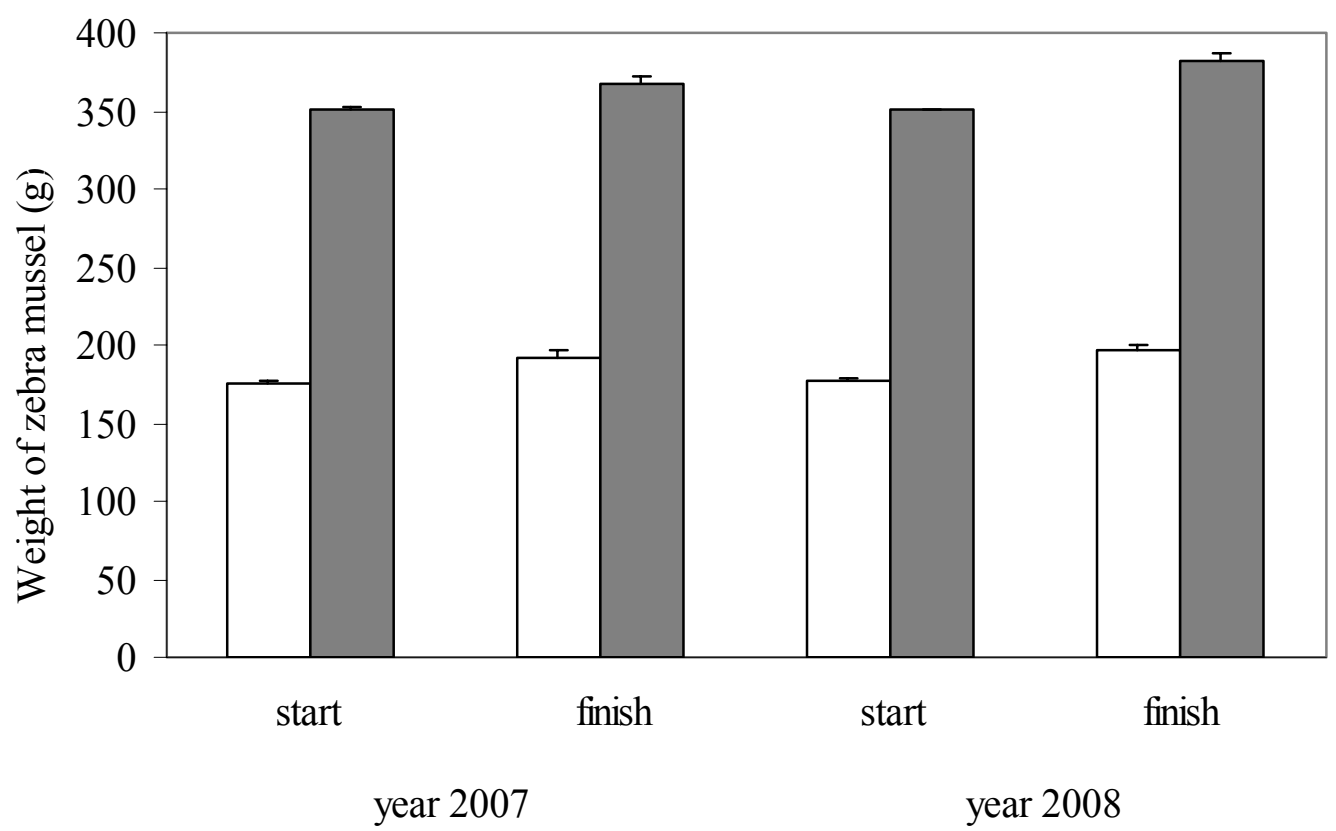

Fig. 1. Weight of Zebra Mussels (g) at start and end of the experiment. White bars Phyto+Dreis A; grey bars - Phyto+Dreis B treatment. Bars represent means of three replicates $\pm \mathrm{SD}$.

In 2007 total dissolved oxygen concentration varied from 9.24 to $10.54 \mathrm{mg} / \mathrm{l}$ in July, from 8.02 to $10.83 \mathrm{mg} / \mathrm{l}$ in August and from 8.12 to $10.88 \mathrm{mg} / \mathrm{l}$ in September. In 2008 the mean values of total dissolved oxygen concentration were higher than in the previous year and fluctuated from 8.90 to $11.70 \mathrm{mg} / \mathrm{l} \mathrm{in} \mathrm{July}$, from 10.34 to $13.76 \mathrm{mg} / \mathrm{l}$ in August and from 9.30 to $14.39 \mathrm{mg} / \mathrm{l}$ in September.

In $2007 \mathrm{pH}$ values varied in all treatments (Fig. 3a) in the range of 8.53-9.39 in Phyto and 8.53-9.6 in mussel-containing treatments, but the differences were not statistically significant (ANOVA $F_{2,9}=0.91 ; \mathrm{P}=0.44$ ). However, in $2008 \mathrm{pH}$ differed significantly between treatments (ANOVA $F_{2,9}=102.72 ; \mathrm{P}<0.001$ ).

The lowest $\mathrm{pH}$ was observed in Phyto (8.97-8.30 and the last value 7.47). In Zebra Mussel treatments $\mathrm{pH}$ values fluctuated similarly (8.64-9.20) during the first 
a) year 2007

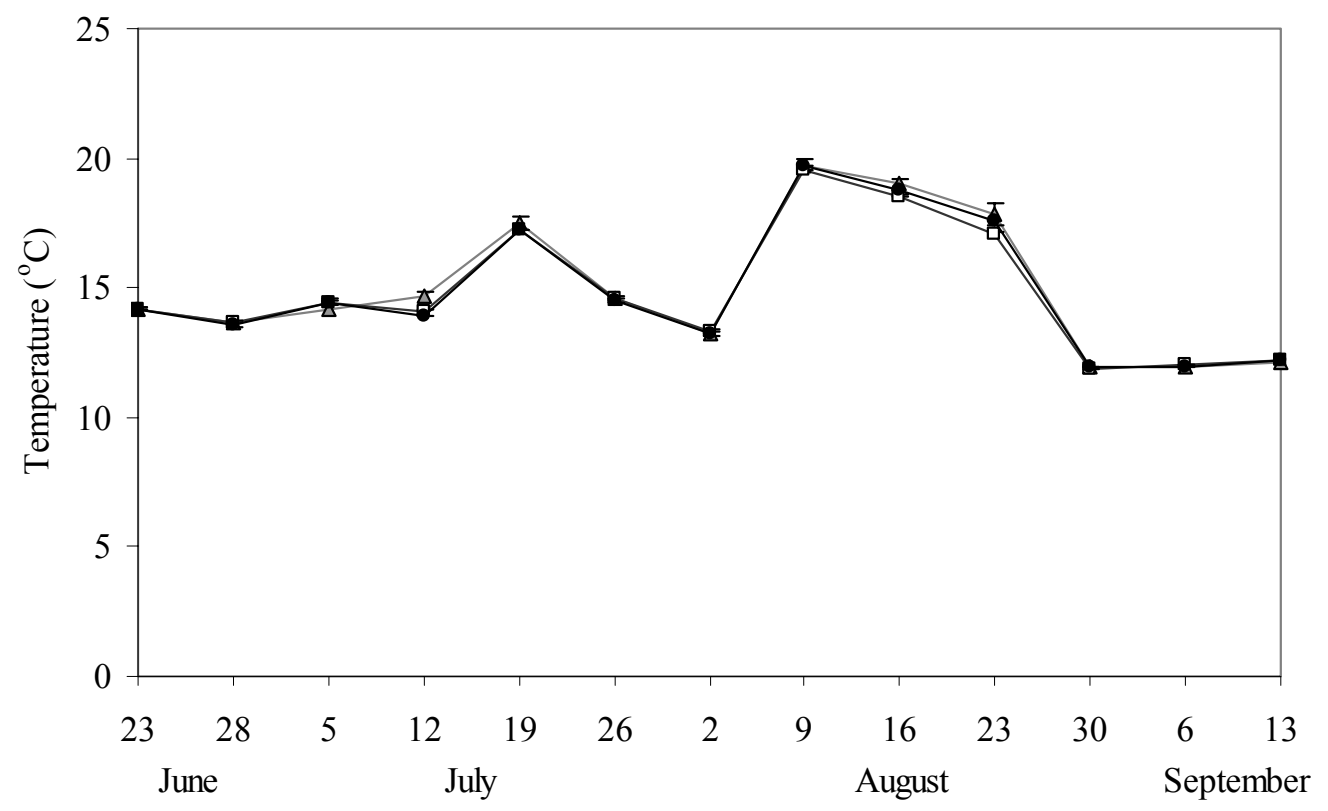

b) year 2008

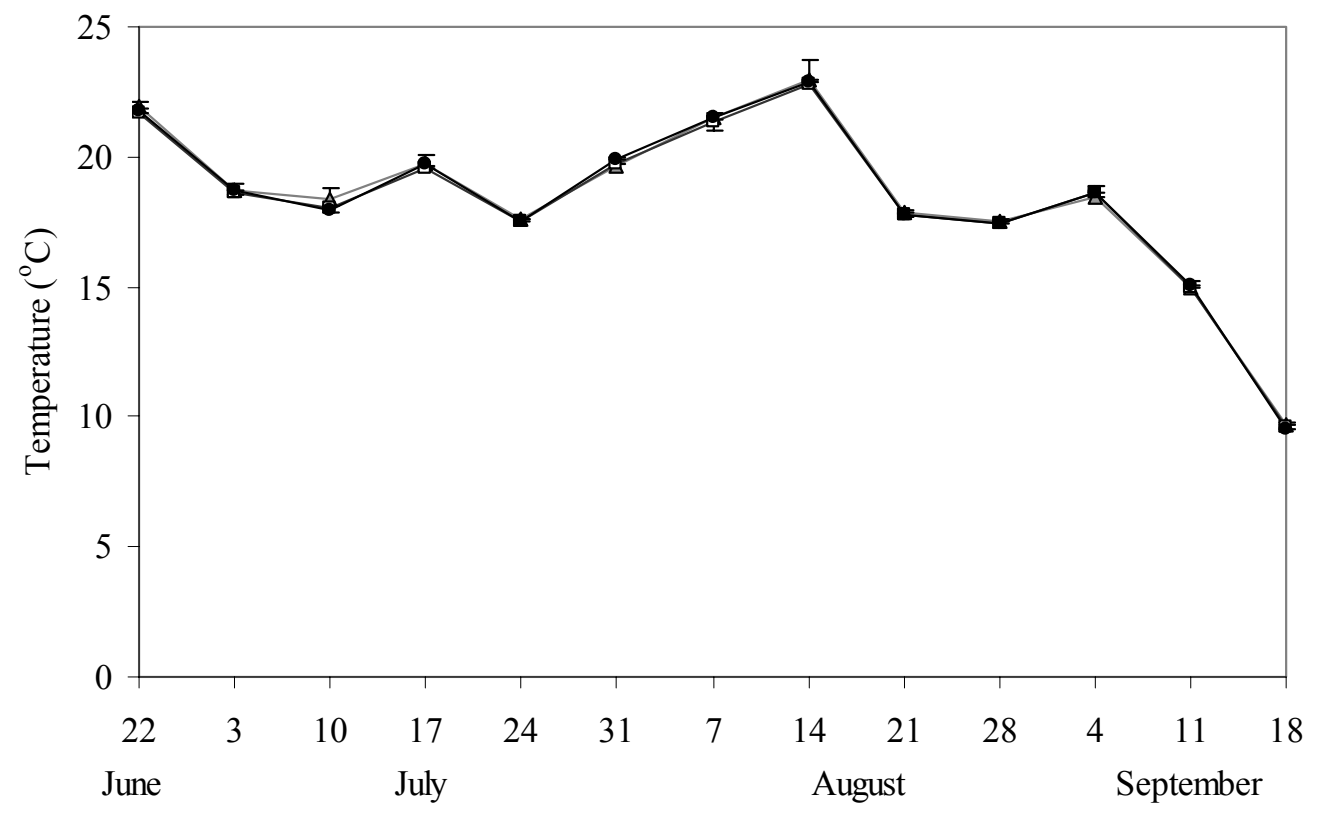

Fig. 2. Water temperature $\left({ }^{\circ} \mathrm{C}\right)$ in: a) year 2007 , and b) year 2008. Grey triangles Phyto; white squares - Phyto+Dreis A; black circles - Phyto+Dreis B. Points represent means of three replicates \pm SD. 
a) year 2007

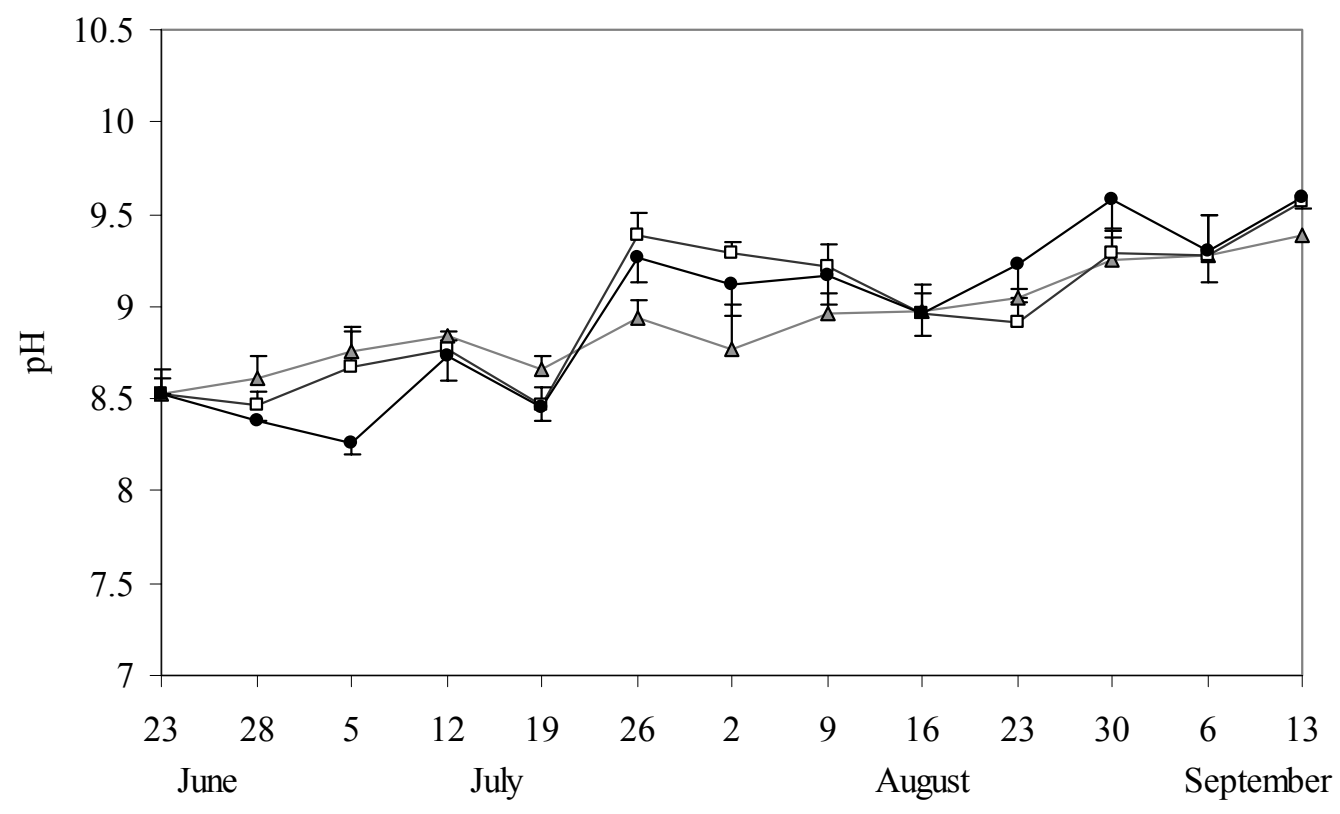

b) year 2008

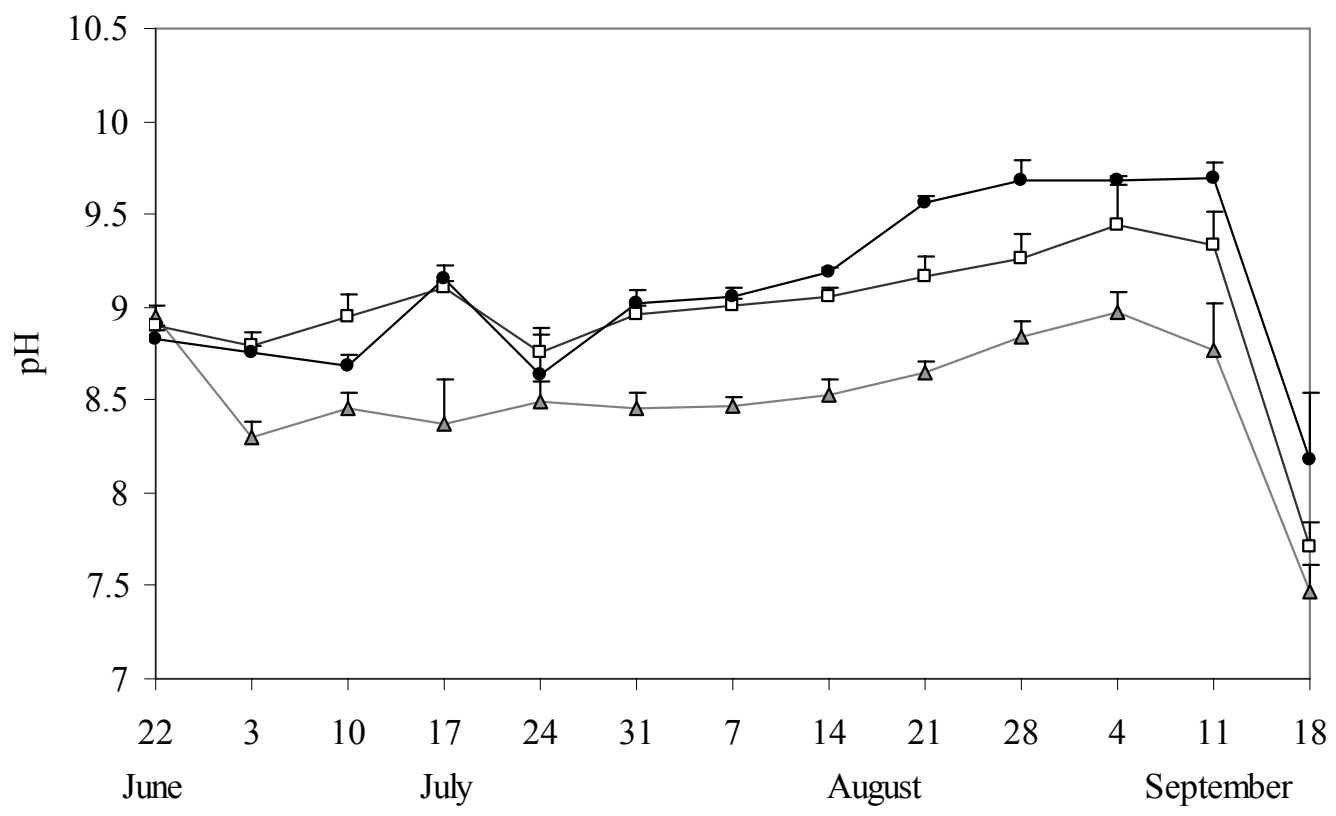

Fig. 3. Water pH in: a) year 2007, and b) year 2008. Grey triangles - Phyto; white squares - Phyto+Dreis A; black circles - Phyto+Dreis B. Points represent means of three replicates $\pm \mathrm{SD}$. 
half of the experiment. From 14 August $\mathrm{pH}$ significantly increased in Phyto+Dreis $\mathrm{B}$, achieving a maximal value of 9.70 (Fig. 3b). In the last week of the experiment $\mathrm{pH}$ decreased rapidly in all treatments, which was probably connected with the slowdown of the biological processes due to considerable fall in temperature. Direct effect of temperature on $\mathrm{pH}$ was not observed in this study.

\subsection{Concentration of magnesium and calcium ions}

The values of both magnesium and calcium ion concentrations were substantially lower in 2007 than in 2008. Analysis of covariance showed a significant influence of chlorophyll $a$ concentrations on magnesium concentrations in 2007 but not in 2008 (ANCOVA: $\mathrm{F}_{1,34}=6.78 ; \mathrm{P}=0.014$ and $\mathrm{F}_{1,34}=0.202 ; \mathrm{P}=0.656$, respectively), yet magnesium concentrations differed significantly between treatments in both 2007 (ANCOVA $\mathrm{F}_{2,34}=9.54 ; \mathrm{P}<0.001$ ) and 2008 (ANCOVA $\mathrm{F}_{2,34}=4.71 ; \mathrm{P}=0.016$ ), showing the dominant role of the Zebra Mussel in reducing the quantity of these ions. In both cases, the values were higher in Phyto than in the Zebra Mussel treatments (Fig. 4a,b). In 2007, Mg concentration in Phyto ranged 0.52-0.62 mg/l. In mussel treatments magnesium concentration fluctuated similarly until the beginning of August, achieving the minimal values of 0.36 and maximal of $0.51 \mathrm{mg} / \mathrm{l}$. In the Phyto+Dreis B treatment, the concentration of $\mathrm{Mg}$ ion rapidly decreased to $0.19 \mathrm{mg} / 1$ (Fig. 4a). In 2008, differences of $\mathrm{Mg}$ ion concentration between treatments appeared earlier and were clearer than in 2007. During the first week of the experiment, values of magnesium concentration suddenly decreased in all treatments. Then, they stabilised in the range $0.87-1.10 \mathrm{mg} / \mathrm{l}$. In mussel treatments $\mathrm{Mg}$ concentrations started to decrease significantly from 17 July and fluctuated in the range $0.75-0.46 \mathrm{mg} / \mathrm{l}$ in Phyto+Dreis A and $0.41-0.18 \mathrm{mg} / \mathrm{l}$ in Phyto+Dreis B (Fig. 4b).

Calcium ion concentrations, analogically to magnesium, differed significantly between control (Phyto) and mussel treatments both in 2007 (ANOVA $\left.\mathrm{F}_{2,9}=24.74 ; \mathrm{P}<0.001\right)$ and in $2008\left(\mathrm{ANOVA} \mathrm{F}_{2,9}=56.19 ; \mathrm{P}<0.001\right)$. 
a) year 2007

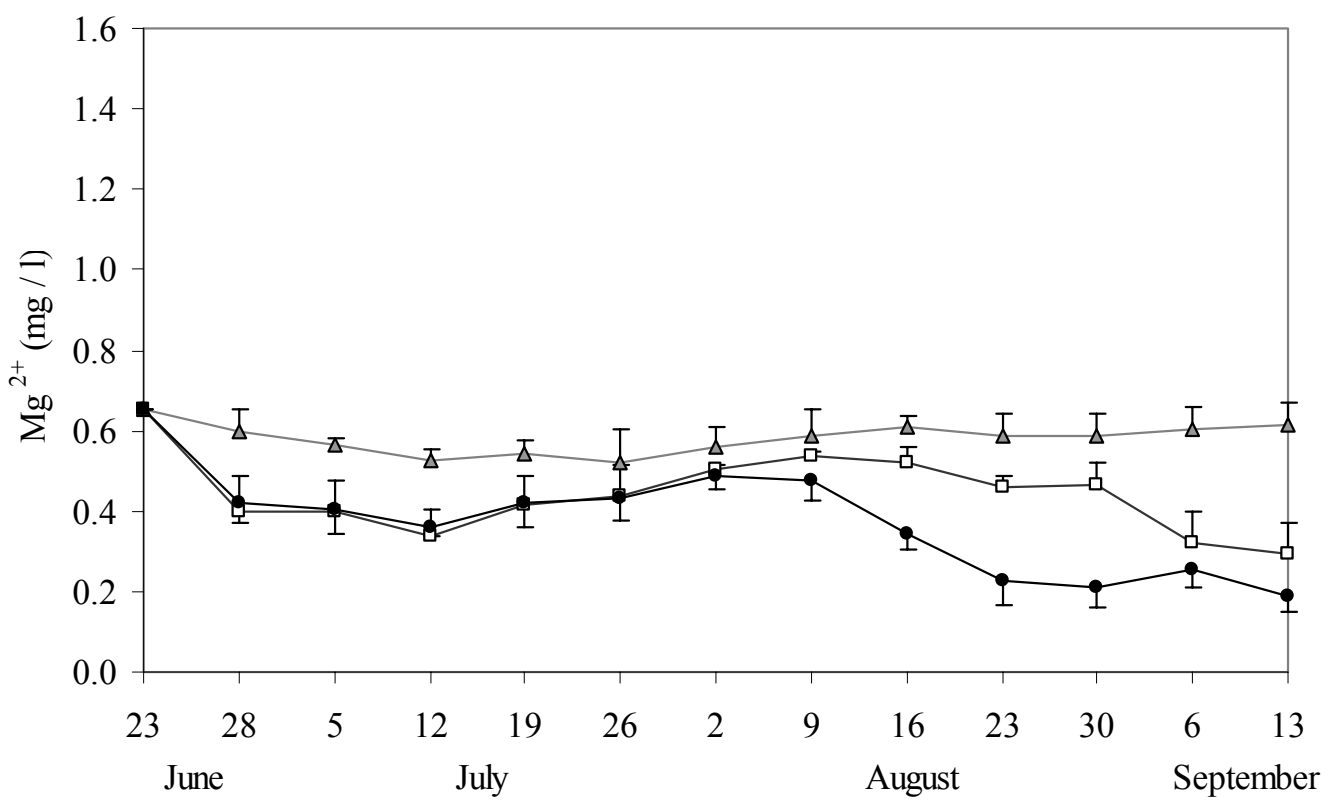

b) year 2008

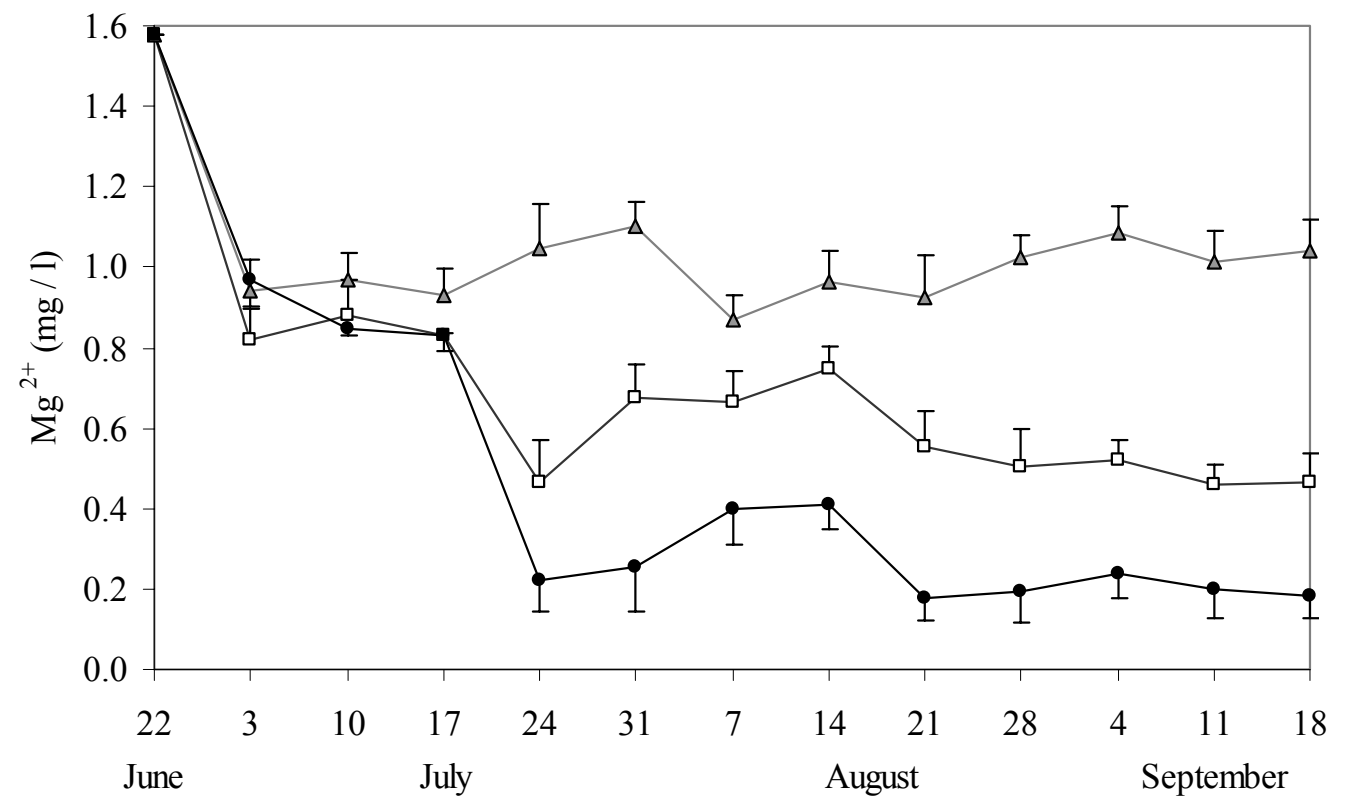

Fig. 4. The concentrations of magnesium ion $(\mathrm{mg} / \mathrm{l})$ in three treatments of the experiment in: a) year 2007, and b) year 2008. Grey triangles - Phyto; white squares - Phyto+Dreis A; black circles - Phyto+Dreis B. Points represent means of three replicates $\pm \mathrm{SD}$. 
a) year 2007

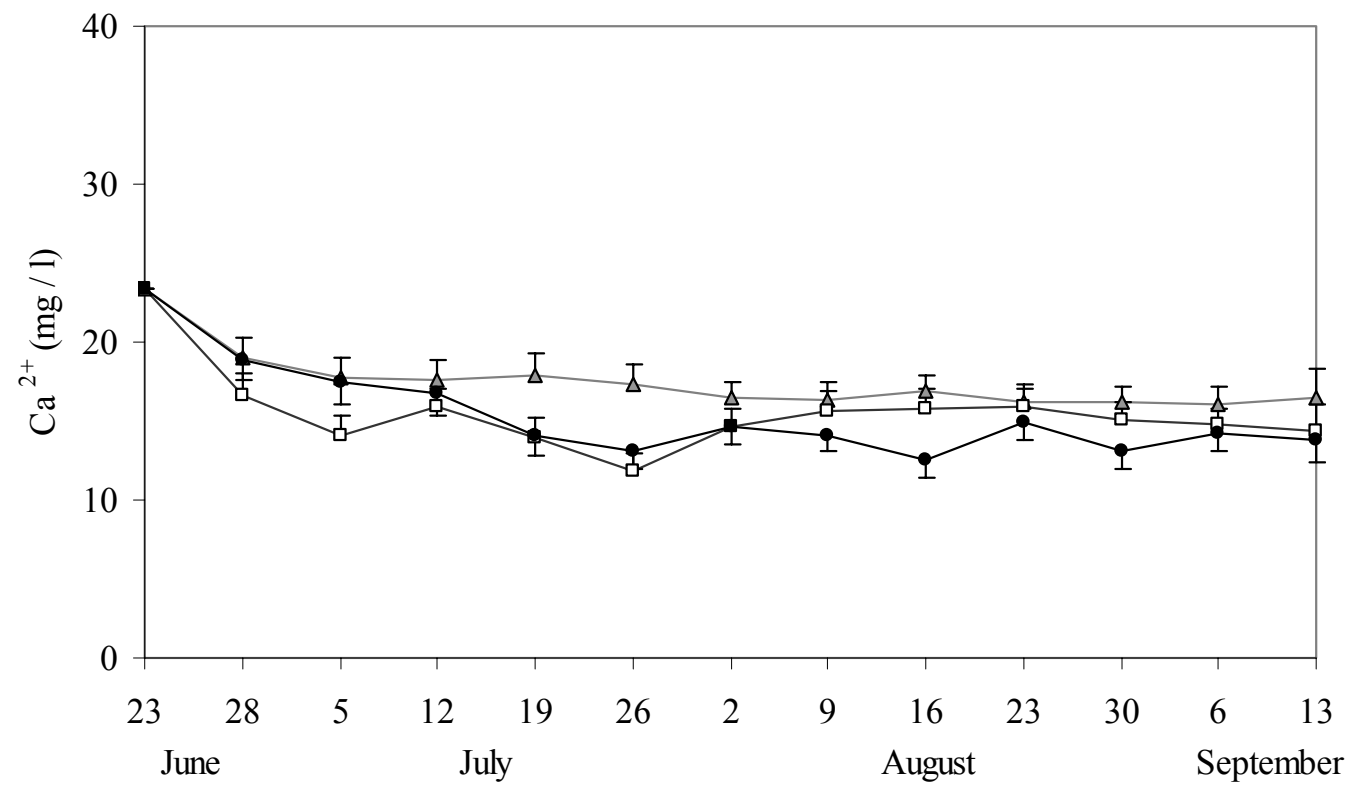

b) year 2008

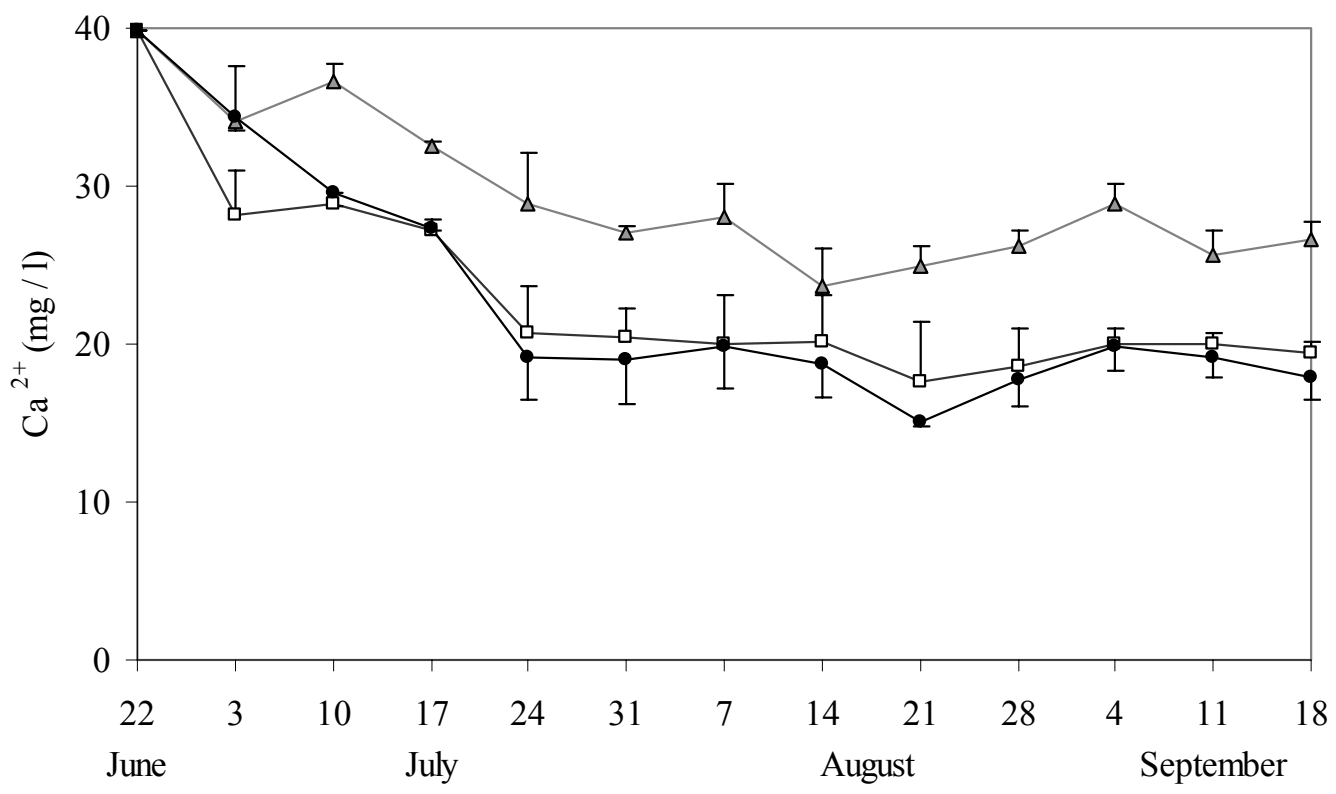

Fig. 5. The concentrations of calcium ion $(\mathrm{mg} / \mathrm{l})$ in three treatments of the experiment in: a) year 2007, and b) year 2008. Grey triangles - Phyto; white squares - Phyto+Dreis A; black circles - Phyto+Dreis B. Points represent means of three replicates $\pm \mathrm{SD}$. 
However, the differences in Ca concentration between treatments seemed to be less visible in 2007; they ranged from 18.9-15.05 mg/l in Phyto, 18.9-11.77 mg/l in Phyto+Dreis A, and 18.9-12.55 mg/1 in Phyto+Dreis B (Fig. 5a). In 2008, we observed the decreasing tendency in $\mathrm{Ca}$ ion concentration in all treatments, but it was the most pronounced in mussel treatments (Fig. 5b). In the control, the calcium concentration fluctuated from 36.67 to $23.65 \mathrm{mg} / \mathrm{l}$. From $24 \mathrm{July}$, Ca concentration stabilised both in Phyto+Dreiss A and Phyto+Dreiss B treatments in the ranges 20.71-17.6 and 19.91-15.07 mg/1 respectively.

\subsection{Physical-chemical correlations}

Values of Pearson's correlation coefficient indicated a significant positive relationship between magnesium and calcium ion concentrations in both 2007 $(\mathrm{r}=0.632 ; \mathrm{P}<0.001)$ and $2008(\mathrm{r}=0.889 ; \mathrm{P}<0.001)$. In 2007 magnesium and calcium concentrations were negatively correlated with $\mathrm{pH}(\mathrm{r}=-0.33 ; \mathrm{P}=0.040$ and $\mathrm{r}=-0.582$; $\mathrm{P}<0.001$, respectively). We did not find significant correlations of either $\mathrm{Mg}$ or $\mathrm{Ca}$ with temperature in this year.

In 2008 negative correlations of both magnesium $(\mathrm{r}=-0.392 ; \mathrm{P}=0.014)$ and calcium concentration $(\mathrm{r}=-0.348 ; \mathrm{P}=0.030)$ with $\mathrm{pH}$ were also observed. Magnesium ion concentrations in mussel treatments were positively correlated with temperature $(\mathrm{r}=0.45 ; \mathrm{P}=0.023)$, whereas we did not find such a correlation in the control $(\mathrm{r}=0.157 ; \mathrm{P}=0.610)$. There was also no correlation between calcium and temperature.

\subsection{Concentration of chlorophyll $a$}

At the start of the experiment, chlorophyll $a$ concentration amounted to 22.91 $\mu \mathrm{g} / 1$ in 2007 and $44.26 \mu \mathrm{g} / 1$ in 2008. Despite such differences, the changes of Chl $a$ dynamics were similar in both study years (Fig. 6a,b). During the first month of the study, Chl $a$ concentrations decreased in all treatments. Subsequently, in Zebra Mussel treatments, the biomass of algae started to increase and achieved maximal concentrations of chlorophyll $a$ in the beginning of September 2007 as well as in 2008 (in Phyto+Dreis B: 78.10 and $76.50 \mu \mathrm{g} / 1$ in 2007 and 2008, respectively). 
a) year 2007

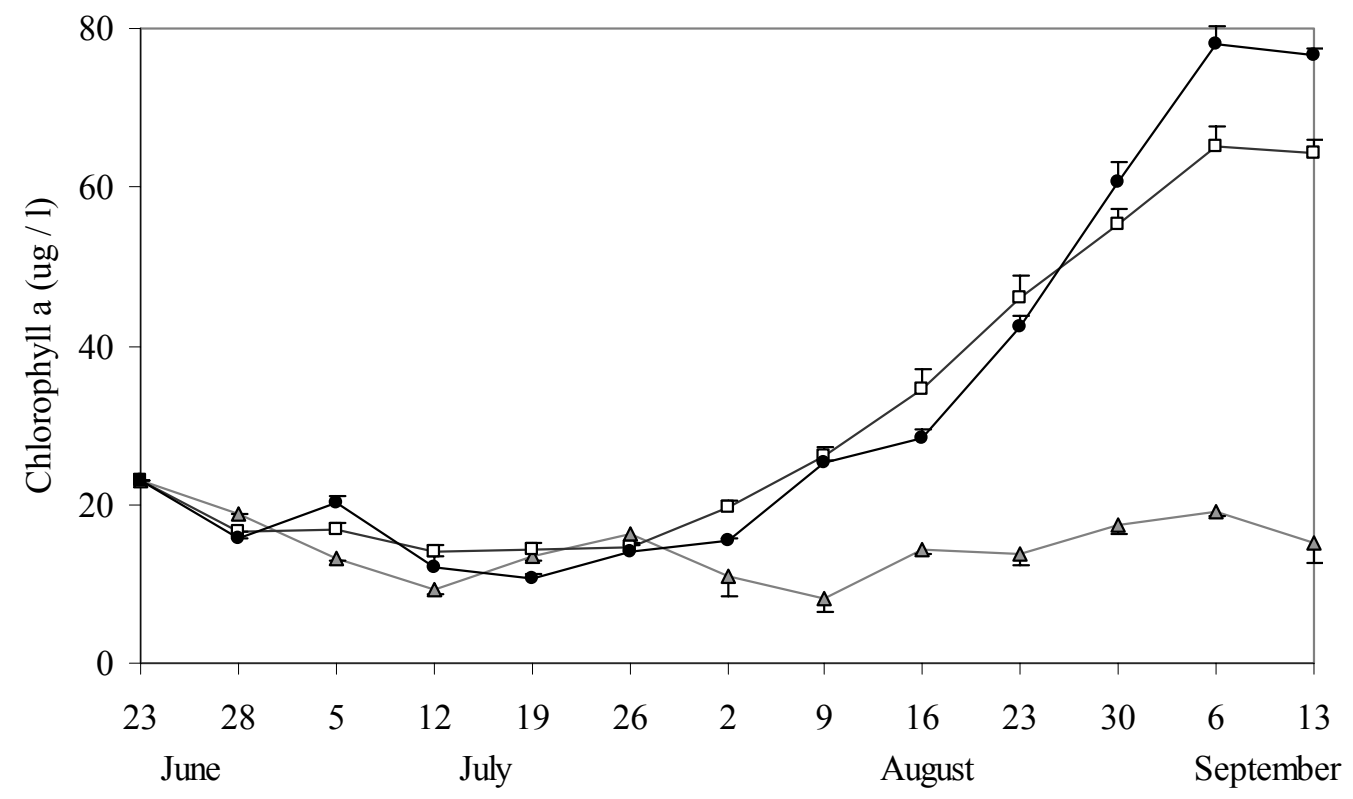

b) year 2008

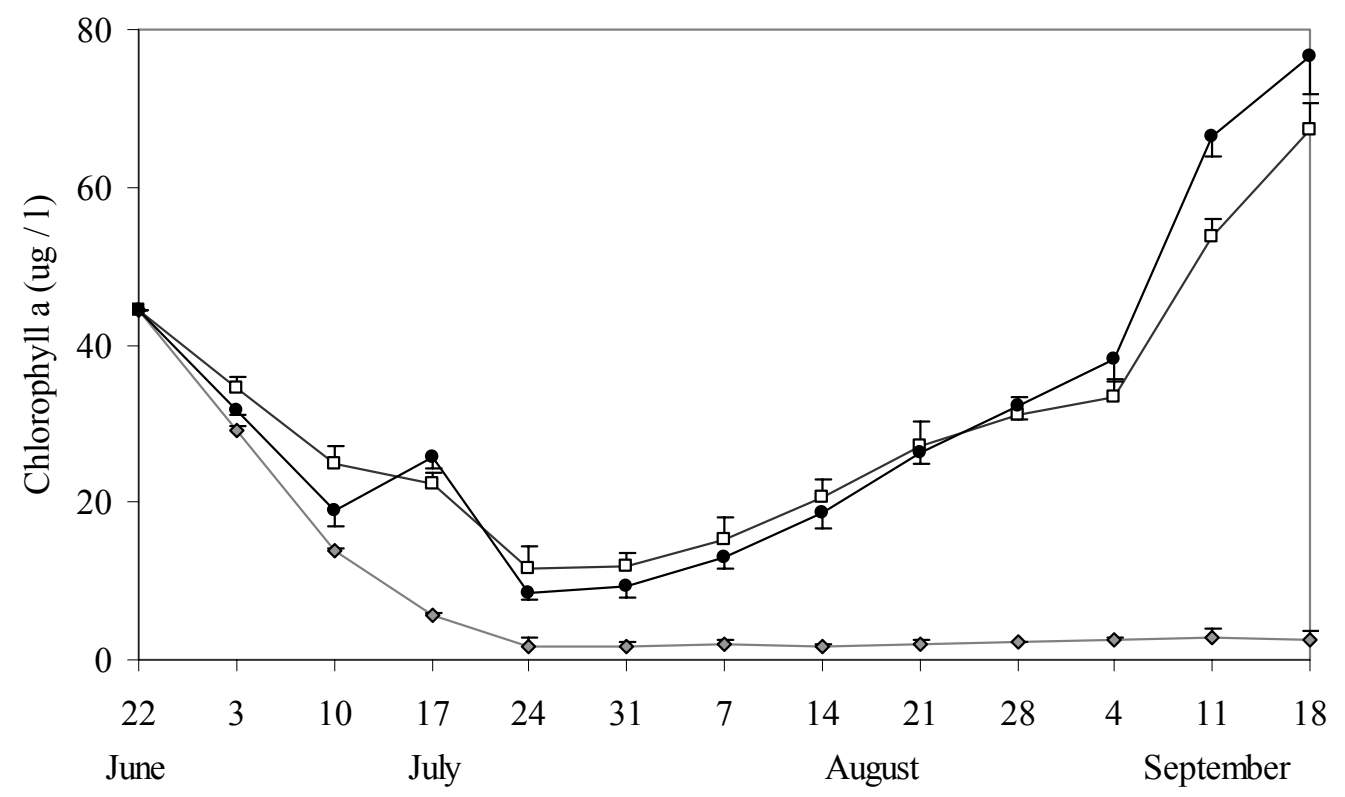

Fig. 6. The chlorophyll $a$ concentrations $(\mu \mathrm{g} / \mathrm{l})$ in three treatments of the experiment in: a) year 2007, and b) year 2008. Grey triangles - Phyto; white squares Phyto+Dreis A; black circles - Phyto+Dreis B. Points represent means of three replicates \pm SD. 
In the control, Chl a concentration was low until the end of the study in both years $(15.10 \mu \mathrm{g} / 1$ in 2007 and $2.68 \mu \mathrm{g} / 1$ in 2008; Fig. 6a,b). These differences between lower Chl $a$ concentrations in the control and higher Chl $a$ concentrations in both Zebra Mussel treatments were significant (ANOVA $\mathrm{F}_{2,36}=3,93 ; \mathrm{P}<0.029$ and $\mathrm{F}_{2,36}=7,42 ; \mathrm{P}<0.002$ in 2007 and 2008 , respectively).

\section{DISCUSSION}

\subsection{Magnesium and calcium roles and dynamics}

Magnesium is one of the fundamental cations of the mineral complex in all animal and plant tissues, insuring the correct course of catabolic and anabolic processes (PLESHCHITSER 1955). It has an unusual importance for Zebra Mussels, as many studies have shown that this species cannot survive in $\mathrm{Mg}$-deficient water (DIETZ et al. 1994). Elevated $\mathrm{Mg} / \mathrm{Ca}$ molar ratios in the surrounding water favour the precipitation of aragonite $\mathrm{CaCO}_{3}$-deposits over calcite, which indicates the crucial, regulatory role of magnesium in Zebra Mussel shell production (CHECA et al. 2007; HALlstan et al. 2010). DiETZ and co-workers (1994) have also indicated the exceptional importance of magnesium in Zebra Mussel osmoregulation. The sensitivity of Zebra Mussels to Mg deficits in water is probably an effect of the limited ability of the organism to reduce its rate of magnesium loss, which results from a high passive permeability to $\mathrm{Mg}$ by mantle or gill epithelia and substantial urinary loss of $\mathrm{Mg}$ (DIETz et al. 1994). Severe decreases in the amount of magnesium ions in Zebra Mussel hemolymph and tissues are especially pronounced during stress (MARTEM'YANOV 2000). Considering, the fact that the $\mathrm{Mg} / \mathrm{Ca}$ molar ratio in lakes is from 7 to even 43 times lower than in oceans, magnesium becomes a limiting factor in the physiology and shell production of Zebra Mussels in freshwater ecosystems (HALLSTAN et al. 2010). Immense demands of Zebra Mussels for magnesium are shown in our study. The presented results, especially from the year 2008, indicated a significant influence of Zebra Mussels on magnesium ion concentrations in water (Fig. 4). Analyzing Mg concentration changes in 2008 (Fig. $4 \mathrm{~b}$ ), it seems that the impact of mussels was abundance-dependent, as $\mathrm{Mg}$ loss was proportional to Zebra Mussel biomass. However, these differences were not 
statistically significant. Furthermore, in both study years, concentrations of magnesium held to the same level of $0.2 \mathrm{mg} / \mathrm{l}$ in Phyto+Dreis B treatments during the last 4-5 weeks of the experiment (Fig. 4), despite the different physical conditions.

In 2008 changes of $\mathrm{Mg}$ concentrations in water were correlated with temperature, but only in Zebra Mussel treatments (not in control), which may show that physiological processes of mussels connected with uptake or/and loss of $\mathrm{Mg}$ are reliant on temperature. In 2007, we observed similar tendencies, but they were not significant, probably because much lower mean temperature (Fig. 2a) decreased the biological activity of the Zebra Mussels. Due to this effect, the influence of $D$. polymorpha on changes in $\mathrm{Mg}$ concentration in this year was not as clear as it was in 2008.

In our study both magnesium and calcium ion concentrations were negatively correlated with $\mathrm{pH}$, which was reflected in the observed trends; concentration of $\mathrm{Mg}$ and $\mathrm{Ca}$ decreased and $\mathrm{pH}$ values increased during the experiment (Fig. 3, 4, 5). In both Zebra Mussel treatments, $\mathrm{pH}$ increased during the daytime due to the intensive uptake of carbon dioxide by algae during photosynthesis (Fig. 6). The range of $\mathrm{pH}$ influences the physiological ion balance of Zebra Mussels. VINOGRADOV and coworkers (1993) indicated that loss of calcium to the external environment significantly increases at $\mathrm{pH}$ values below 7.0. This process may result in Zebra Mussel mortality. Conversely, the increase of $\mathrm{pH}$ simultaneously causes an increased influx of calcium to the Zebra Mussel's body (VINOGRADOv et al. 1993), a finding that may elucidate our results. In 2008, in mussel treatments, $\mathrm{pH}$ exceeded the value of 9.6 , probably because of the high rate of $\mathrm{CO}_{2}$ uptake by intensively photosynthesising green algae. However, despite such a $\mathrm{pH}$ value being recognised as the upper tolerance limit of Zebra Mussels, (Bowman, BAILEY 1998) we observed permanent filtering activity of Zebra Mussels with no signs of mortality. Increase of Zebra Mussel weight on the end of the study in both years (Fig. 1) confirms that animals stayed alive and physiological active in the experiment duration. 
The abundance of calcium is reported by some authors (e.g. RAMCHARAN 1992) to be the main predictor for the occurrence of Zebra Mussels, which reflects its importance for the mussel's viability. Calcium is involved in muscular contractions, cellular cohesion, nervous functions and the maintenance of $\mathrm{pH}$ (CHÉTAIL, KRAMPITZ 1982), and of course, it is indispensable to shell growth in the form of calcium carbonate (PIECHOCKI, DYDUCH-FALNIOWSKA 1993). In our experiment, calcium loss was significantly larger in mussel treatments than in the controls, but this effect was not as clear as it was for magnesium (Fig. 4, 5). Results were again more obvious in 2008 than in 2007; in mussel treatments calcium concentrations decreased from 39.87 to mean $19 \mathrm{mg} / 1$ and oscillated around this level to the end of study (Fig. 5b). Zebra Mussels require $\mathrm{Ca}$ ion concentrations greater than $12 \mathrm{mg} / \mathrm{l}$ to establish a significant population, which is considerably higher than what is required by other bivalve molluscs (typically 3-4 mg/l) (HEATH 1993). The upper Ca limit is not unambiguously known, e.g. O’NeILL (1996) indicates a high colonisation potential of Zebra Mussels over a calcium range from 25 to even $>125 \mathrm{mg} / \mathrm{l}$. Even though Zebra Mussels are normally found in water with moderate to high calcium concentrations, they will survive in Ca-poor environments, providing the bathing fluid contains magnesium in minimal amounts (DIETZ et al. 1994). Moreover, mussels survive Ca-deficiency by mobilising calcium from their shells in order to maintain necessary levels of calcium in hemolymph (DIETZ et al. 1994). This fact shows that calcium is not a limiting factor in the Zebra Mussel's biology, as is magnesium.

\subsection{Reduction of the excessive magnesium input to freshwater ecosystems}

The important sources of magnesium in freshwater ecosystems are fertilizers used in agriculture and organic pollutants from farms, such as animal faeces and herbal food residue (SAPEK 2007). Magnesium from these sources gets to the lakes, reservoirs and rivers through ground water or/and surface flow from farming regions. Although, magnesium is not considered a pollutant, reduction of excessive $\mathrm{Mg}$ input to water bodies may be important for water quality, because magnesium, a main component of chlorophyll, has a stimulating effect on algal and cyanobacterial 
growth (e.g. TUBEA et al. 1981; UTKILEN 1982). However, magnesium may be only one of the factors contributing to algal blooms - the most important seem to be nitrogen and phosphorus, both of which amplify the symptoms of eutrophication. In our experiments the highest values of chlorophyll $a$ were observed in treatments with Zebra Mussels (Fig. 6), where, due to a mollusc biological activity, $\mathrm{Mg}$ concentration was low but nutrient loads excreted by Zebra Mussels (P and N) were high (results in WoJTAL-FrankIEwICZ, FrANKIEWICZ 2010) - what indicate that Zebra Mussel may increase water trophy. In order to avoid such a negative effect of Zebra Mussels on water quality in natural ecosystems, strong control of their population size is necessary (WOLNOMIEJSKI, WOŹNICZKA 2008; WIŚNIEWSKI, personal communication). This control may contribute to decrease of an internal input of nutrients and N:P ratio in water (WOJTAL-FrANKIEWICZ, FrANKIEWICZ 2010). For restoring and controlling nutrient input from the catchment area (external input) a complex strategy should be used, according to the interdisciplinary concept for sustainable water resources management (ZALEWSKI 2000). Reduction of magnesium and phosphorus loads is possible by the optimization of agricultural practices and creation of ecotone buffers, where nutrients are transformed into plant biomass. It is especially necessary in the case of improper agricultural management, e.g. monocultural production of crop and livestock, which often destroys the process of residue recycling (PETERSEN 2001). In such cases, the construction or preservation of wetlands at the shore line is crucial for protection against pollutants that inevitably flow from the environment. Moreover, ecotones serve as a productive habitat for species present in adjacent ecosystems, increasing biodiversity and thereby the resistance and resilience of water ecosystems against human impact (SAntiago-FAndino, NeAte 2002). However, this strategy so effective for pollution reduction may be not quite useful for D. polymorpha control. This is because submerged macrophytes are the important substrate for settling of Zebra Mussel's planktonic larvae (veligers) and their availability is one of the main factors responsible for raising the abundance of Zebra Mussel population (KoBAK, WIŚNIEWSKI 1998). 
In conclusion, Zebra Mussels are able to considerably influence the pool of available magnesium in water of inhabited ecosystems. As the presented results indicate, Zebra Mussels have a higher rate of magnesium uptake than do phytoplankton, and they seem to be important $\mathrm{Mg}$ competitors for algae and cyanobacteria. Translocation of magnesium in Zebra Mussel tissues and shells may significantly reduce amount of $\mathrm{Mg}$ accessible for phytoplankton. On the other hand, during times of high phytoplankton abundance, intensive photosynthesis causes an increase of $\mathrm{pH}$, which reduces the level of soluble magnesium in water (RoGER, KULASOORIYA 1980) and may limit the availability of $\mathrm{Mg}$ for Zebra Mussels. Perhaps, limitation of magnesium inflow to freshwater ecosystems may contribute to the reduction of Zebra Mussel expansion, but this process depends on many factors and requires detailed research. We believe that knowledge about impact of Zebra Mussels on magnesium dynamics may be useful for studies focused on methods of controlling not only this invasive species, but also algal blooms.

\section{REFERENCES}

ABraszewsKA, A. 2006. Dynamics of the occurrence of Dreissena polymorpha (Pallas,1771) in the Sulejów Reservoir in 1997-2005. In: B.M. POKRYSZKO (ed.), The 22th Polish Malacological Seminar. Folia Malacol. 14: 85.

Bowman, M.F., BAILEY, R.C. 1998. Upper pH tolerance limit of the Zebra Mussel (Dreissena polymorpha). Can. J. Zool. 76: 2119-2123.

Casagrandi, R., Mari, L., Gatto, M. 2007. Modelling the local dynamics of the Zebra Mussel (Dreissena polymorpha). Freshwat. Biol. 52: 1223-1238.

Cagnard, O., Boudin, I., Lemoigne, I., Cartnick, K. 2006. Assessment of emerging optic sensors (fluoroprobes) for algae on-line monitoring. American Water Works Association WQTC Conference, Denverss, pp. 1-10.

Checa, A.G., Jimenez-Lopez, C., Rodriguez-Navarro, A., Machado J. P. 2007. Precipitation of aragonite by calcitic bivalves in Mg-enriched marine waters. Mar. Biol. (Berl) 150: 819-827.

ChÉTAIL, M., Krampitz, G. 1982. Calcium and skeletal structures in mollusks: concluding remarks. Malacologia 22: 337-339. 
Dietz, T.H., Lessard, D., Silverman, H., LynN, J.W. 1994. Osmoregulation in Dreissena polymorpha: the importance of $\mathrm{Na}, \mathrm{Cl}, \mathrm{K}$, and particularly $\mathrm{Mg}$. Biol. Bull. 187: 76-83.

Hallstan, S., Grandin, U., GoedKoop, W. 2010. Current and modeled potential distribution of the zebra mussel (Dreissena polymorpha) in Sweden. Biol. Invasions 12: 285-296.

HeAtH, R.T. 1993. Zebra Mussel Migration To Inland Lakes And Reservoirs: A Guide For Lake Managers, Kent State University, Ohio Sea Grant College Program, online at http://www.sgnis.org/publicat/managers.htm.

Horohov, J., Silverman, H., LynN, J.W., Dietz, T.H. 1992. Ion transport in the freshwater zebra mussel, Dreissena polymorpha. Biol. Bull. 183: 297-303.

IzydorczyK, K., CARPENTIER, C., MróWCZyŃski, J., WAgenVoOrt, A., JurcZAK, T., TARCZYŃSKA, M. 2009. Establishment of an Alert Level Framework for cyanobacteria in drinking water resources by using the Algae Online Analyser for monitoring cyjanobacterial chlorophyll $\underline{a}$. Water Res. 43: 989-996.

Karatayev, A.Y., Burlakova, L.E., Padilla, D.K. 2002. Impacts of zebra mussels on aquatic communities and their role as ecosystem engineers. In: E. LEPPAKOSKI, S. GOLlASCH, S. OlENIN (eds), Invasive aquatic species of Europe. Distribution, impacts and management, Kluwer Academic Publishers, pp. 433446.

KOBAK, J., WIŚNIEWSKI, R. 1998. Larval settlement and distribution of juveniles of zebra mussel (Dreissena polymorpha Pall., Bivalvia) on selected artificial substrates. AUNC Limnological Papers 20: 25-54.

LEWANDOWSKI, K. 2001. Development of populations of Dreissena polymorpha (Pall.) in lakes. Folia Malacol. 9: 173-216.

MACISAAC, H.J. 1996. Potential abiotic and biotic impacts of Zebra Mussels on the inland waters of North America. Am. Zool. 36: 287-299.

MARTEM'YANOV, V.I. 2000. The dynamics of the sodium, potassium, calcium, magnesium contents in the fresh water mollusc zebra mussel Dreissena polymorpha during stress. J. Evol. Biochem. Physiol. 36: 41-46. 
O’NeILl, Ch.JR. 1996. The zebra mussel impacts and control, New York Sea Grant, Cornell University, State University of New York; Cornell Cooperative Extension, Information Bulletin 238: 1-62.

Petersen, H-G. 2001. Economic aspects of agricultural area management and land/water ecotone conservation. Ecohydrol. Hydrobiol. 1: 97-110.

Piechocki, A., Dyduch-Falniowska, A. 1993. Mięczaki (Mollusca). Małże (Bivalvia). Fauna słodkowodna Polski, 7A, PWN, Warszawa, pp. 1-204.

PleshChitser, A.L. (Gor'KII) 1955. Biological role of magnesium. Adv. Contemp. Biol. XL 1: 52-67.

Ramcharan, C.W., Padilla, D.K., Dodson, S.I. 1992. Models to predict occurrence and density of the zebra mussel, Dreissena polymorpha. Can. J. Fish. Aquat. Sci. 49: 2611-2620.

Richardson, T.L., Lawrenz, E., Pinckney, J.L., Guajardo, R.C., Walker, E.A., PAerl, H.W., MacInTYRE, H.L. 2010. Spectral fluorometric characterization of phytoplankton community composition using the Algae Online Analyser. Water Res. 44: 2461-2472.

Roger, R.A., Kulasooriya, S.A. 1980. Blue-green algae and rice, Los Baños, Laguna, IRRI. pp. 1-112.

Santiago-Fandino, V., Neate, J. 2002. Phytotechnologies and ecohydrology: A comprehensive approach to watershed management. Ecohydrol. Hydrobiol. 2: $39-47$.

SAPEK, A. 2007. Magnesium circulation in environment against the background of oxygen concentration in countryside water resources. Ochrona Środowiska i Zasobów Naturalnych 31: 317-322, Dział Wydawnictw IOŚ.

STAŃCZYKowsKa, A. 1983. Inwazje zwierząt. Przyr. Pol. 5: 20-21.

STRAYER, D.L. 1991. Projected distribution of the zebra mussel, Dreissena polymorpha, in North America. Can. J. Fish. Aquat. Sci. 48: 1389-1395.

TARCZyŃska, M., Romanowska-Duda, Z., Jurczak, T., Zalewski, M. 2001. Toxic cyanobacterial blooms in drinking water reservoir - causes, consequences and management strategy. Wat. Sci. Technol.: Water Supply 1: 237-246. 
Tubea, B., HawXBy, K., Mehta, R. 1981. The effects of nutrient, pH and herbicide levels on algal growth. Hydrobiologia 79: 221-227.

UtKILEN, H.CH. 1982. Magnesium-limited growth of the cyanobacterium Anacystis nidulans. J. Gen. Microbiol. 128: 1849-1862.

Wojtal-Frankiewicz, A., Frankiewicz, P. 2010. The impact of pelagic (Daphnia

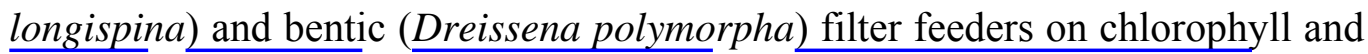
nutrient concentration. Limnologica, DOI:10.1016/j.limno.2010.09.001.

WOLNOMIEJSKI, N., WoźNICZKA, A. 2008. A drastic reduction in abundance of Dreissena polymorpha Pall. in the Skoszewska Cove (Szczecin Lagoon, River Odra estuary): effects in the population and habitat. Ecol. Questions 9: 103-111.

Vinogradov, G.A., Smirnova, N.F., Sokolov, V.A., Bruznitsky, A.A. 1993. Influence of chemical composition of the water on the mollusk Dreissena polymorpha. In: T.F. NALEPA, D.W. SCHLOESSER (eds), Zebra Mussels: biology, impacts, and control, Lewis Publishers, Boca Raton, Florida, pp. 283-293.

ZALEWSKI, M. 2000. Ecohydrology the scientific background to use ecosystem properties as management tool toward sustainability of freshwater resources. Guest editorial Ecol. Eng. 16: 1-8. 